\title{
Techniques for inactivating Toxoplasma gondii oocysts: a systematic review
}

\section{Técnicas para inativar oocistos de Toxoplasma gondii: uma revisão sistemática}

\author{
Fernanda Pinto-Ferreira1* (1); Aline Ticiani Pereira Paschoal'; Aline Kuhn Sbruzzi Pasquali²; \\ Juliana Correa Bernardes ${ }^{1}$; Eloiza Teles Caldart ${ }^{\text {; }}$ Roberta Lemos Freire ${ }^{1}$; Regina Mitsuka-Breganó1; \\ Italmar Teodorico Navarro ${ }^{1}$ \\ ${ }^{1}$ Departamento de Medicina Veterinária Preventiva, Universidade Estadual de Londrina - UEL, Londrina, PR, Brasi \\ 2 Universidade do Oeste de Santa Catarina - UNOESC, Campos Novos, SC, Brasil
}

How to cite: Pinto-Ferreira F, Paschoal ATP, Pasquali AKS, Bernardes JC, Caldart ET, Freire RL, et al. Techniques for inactivating Toxoplasma gondii oocysts: a systematic review. Braz J Vet Parasitol 2021; 30(2): e026420. https://doi.org/10.1590/S198429612021040

\begin{abstract}
The oocyst, a resistant form of Toxoplasma gondii, plays an important role in the transmission of this protozoan. The objective of this review was to report the methods capable of inactivating oocysts through a systematic review of the literature carried out in the Scientific Electronic Library Online, Web of Science, Science Direct, PubMed and Scopus databases. The keywords searched were (((effects OR infectivity OR resistance) AND Toxoplasma) AND oocyst). We selected 16 articles that described 309 different treatments. Among all the protocols evaluated, $35.60 \%$ (110/309) were effective in inactivating oocysts. Physical methods were more effective than other methods $(p<0.05)$. Sporulated oocysts and the T. gondii VEG strain were more resistant $(p<0.05)$ to treatments. Although it is effective against viruses and bacteria, the use of disinfectants in water has little or no effect on $T$. gondii oocysts. The use of radiation and pressure were effective in inactivating oocysts, as these treatments do not include changes in temperature, they can be used in foods for raw consumption, such as vegetables, as it will not cause substantially changes in their physical and chemical characteristics. Therefore, these methods can be viable alternatives for the control of $T$. gondii.
\end{abstract}

Keywords: Chemical, physical, irradiation, decontamination.

\section{Resumo}

O oocisto, forma resistente do Toxoplasma gondii, desempenha um papel importante na transmissão desse protozoário. $O$ objetivo desta revisão foi relatar os métodos capazes de inativar oocistos por meio de uma revisão sistemática da literatura realizada nas bases de dados Scientific Electronic Library Online, Web of Science, Science Direct, PubMed e Scopus. As palavras-chave pesquisadas foram (((efeitos OR infectividade OR resistência) AND Toxoplasma) AND oocyst). Foram selecionados 16 artigos que descreveram 309 tratamentos diferentes. Dentre todos os protocolos avaliados, 35,60\% (110/309) foram eficazes na inativação de oocistos. Os métodos físicos foram mais eficazes do que outros métodos $(p<0,05)$. Oocistos esporulados e a cepa VEG de $T$. gondii foram mais resistentes $(p<0,05)$ aos tratamentos. Embora seja eficaz contra vírus e bactérias, o uso de desinfetantes na água tem pouco ou nenhum efeito sobre os oocistos de $T$. gondii. $\mathrm{O}$ uso de radiação e pressão foram eficazes na inativação de oocistos. Como esses tratamentos não incluem mudança de temperatura, podem ser utilizados em alimentos de consumo cru, tais como vegetais, pois não acarretarão substancialmente alterações nas suas características físico-químicas. Portanto, esses métodos podem ser alternativas viáveis para o controle de T. gondii.

Palavras-chave: Química, física, irradiação, descontaminação. 


\section{Introduction}

Toxoplasma gondii infection occur via transplacental transmission or consumption of contaminated food and water. Ingestion of raw or undercooked meat containing tissue cysts (bradyzoites), dairy products containing tachyzoites, and fruits and vegetables that were in contact with soil contaminated with oocysts (sporozoites) can all transmit this protozoan (Tenter et al., 2000; Dabritz \& Conrad, 2010; Pinto-Ferreira et al., 2019).

The parasite has a complex life cycle with an asexual phase that occurs in warm-blooded animals, including felines. However, the sexual phase occurs only in felines, which are the definitive hosts, and results in the excretion of oocysts within 3-7 and over 14 days after ingestion of bradyzoites and tachyzoites, respectively (Frenkel et al., 1970; Dubey \& Beattie, 1988; Lafferty, 2006; Dubey, 1997). When infected with the tissue cysts, domestic cats can eliminate up to a billion oocysts within a period of one or two weeks (Dubey \& Frenkel, 1972). These oocysts get excreted in the non-sporulated form and need to sporulate to become infectious (Dubey et al., 1970b).

In a study on toxoplasmosis outbreaks, Pinto-Ferreira et al. (2019) suggested that the popularization of freezers and improvements in animal handling and hygiene have substantially reduced the formation and viability of meat cysts. Despite these improvements, serum prevalence of antibodies against $T$. gondii in humans remains relatively high in most countries, suggesting that water, vegetables, and soil could be important routes of transmission (Cole et al., 2011; Ferreira et al., 2018).

The oocyst is an environmentally resistant stage of the protozoan that plays an important role in the epidemiology of this zoonotic parasite (Tenter et al., 2000; Dumètre et al., 2013). The ability of $T$. gondii oocysts to survive extremely diverse conditions is conferred by its cell wall, which is composed of two complex and resistant layers that protect the protozoan until it is ingested by the host (Dumètre et al., 2013). Although methods for inactivating T. gondii are quite effective in other biological stages of the parasite, no specific recommendations have been made for oocysts. However, decontaminating of drinking water and fresh food that may be carrying oocysts requires greater attention (AWWA, 1999) because the wall of the infectious agent acts as a primary barrier to physical and chemical attacks (Dumètre et al., 2013). The objective of this systematic review was to determine the major techniques used to inactivate $T$. gondii oocysts.

\section{Materials and Methods}

The Scientific Electronic Library Online (SciELO), Web of Science, Science Direct, PubMed, and Scopus databases were used to carry out this systematic review. The keywords used were (((effects OR infectivity OR resistance) AND Toxoplasma) AND oocyst). Two researchers independently collected data in 2019. The main question that we addressed in this review was: what is the most efficient method to inactivate $T$. gondii oocysts in water and vegetables?

English and Portuguese research articles that mentioned techniques to inactivate $T$. gondii oocysts in the abstract were included. Articles with inactivation of other biological forms, such as cysts and tachyzoites, were excluded, as well as, only studies that evaluated effectiveness through bioassay in mice were selected. Were considered effective only the protocols that inactivated the oocysts, sporulated or not, to the point of not leading any inoculated mice to death. From each study, the following data were extracted: type of treatment (chemical or physical), number of oocysts inoculated, temperature, concentration of chemical of physical agent, strain of the protozoan, time of exposure, and effectiveness of the protocol. The software program Mendeley (Elsevier, Amsterdam, Netherlands) was used to organize, delete, and research articles.

Microsoft Excel (Microsoft, Redmond, WA, USA) was used to tabulate the different variables and the efficacy of the treatments found in the selected papers. Epi Info 7.2.3.1 (CDC (Centers for Disease Control and Prevention), Atlanta, Georgia, USA) was used to generate data for the frequency tables and bivariate analysis. Only variables with p-values less than 0.20, as determined via Chi-square test or Fisher's exact test, were included in the logistic regression models. Simple and multiple logistic regression modeling was performed using R Studio 1.2.5033 in the R 3.6.2 environment (R Foundation for Statistical Computing, 2013). Only variables with p-values less than 0.05 were considered statistically significant. The degree of correlation was assessed via the odds ratio (OR) calculation with a $95 \%$ confidence interval (Cl).

We performed multiple correspondence analysis with the FactoMineR package (http://factominer.free.fr). This technique does not rely on statistical tests and provides visualization of the most relevant relationships in a large set of variables (Lebart et al., 1984). 


\section{Results}

After searching the search bases with the keywords (((effects OR infectivity OR resistance) AND Toxoplasma) AND oocyst), 625 articles in total were found in the following (the number of articles from each database is given in parentheses): SciELO (1), Web of Science (110), PubMed (117), Science Direct (198), and Scopus (199). Incomplete or duplicate articles, those with missing titles, authors, or abstracts, and those with themes not related to the objective of the study were excluded. For the analysis of the treatment methods, we selected 16 articles, which described 309 different treatments for inactivating T. gondii oocysts.

Of the treatment methods analyzed, 23.62\% (73/309) were chemical treatments whereas the remaining $76.38 \%$ (236/309) were physical treatments. Physical methods were further divided into temperature-based (63.55\%; 150/236), radiation-based (33.05\%; 78/236), and pressure-based treatments (3,38\%; 8/236) (Table 1). In 83.50\% (258/309) of the protocols, sporulated oocysts were treated whereas in the remaining $16.50 \%(51 / 309)$ protocols, non-sporulated oocysts were treated.

Table 1. Frequencies of different physical and chemicals methods used for the inactivation of Toxoplasma gondii oocysts reported in the literature, 1973-2019.

\begin{tabular}{|c|c|c|c|}
\hline & Techniques analyzed \% (n/N) & Most used techniques & $\%$ \\
\hline \multirow[t]{8}{*}{ Physical } & $76.38 \%$ (236/309) & Heating & $20.06 \%$ \\
\hline & & Ultraviolet & $19.74 \%$ \\
\hline & & Cooling & $14.89 \%$ \\
\hline & & Freezing & $5.83 \%$ \\
\hline & & Irradiation gamma & $5.50 \%$ \\
\hline & & Thermal shock & $5.18 \%$ \\
\hline & & Room temperature & $2.59 \%$ \\
\hline & & Pressure & $2.59 \%$ \\
\hline \multirow[t]{9}{*}{ Chemicals } & $23.62 \%(73 / 309)$ & Alcohol & $6.80 \%$ \\
\hline & & Acid & $3.24 \%$ \\
\hline & & $\mathrm{NaCl}$ & $3.24 \%$ \\
\hline & & Antibiotic & $2.91 \%$ \\
\hline & & Phenol & $2.27 \%$ \\
\hline & & Formaldehyde & $2.27 \%$ \\
\hline & & Base & $1.60 \%$ \\
\hline & & Antiseptic & $0.97 \%$ \\
\hline & & Aldehyde & $0.32 \%$ \\
\hline
\end{tabular}

$(\mathrm{n} / \mathrm{N})$ : $\mathrm{n}$ : sample number and N: population number.

We observed that $35.60 \%$ (110/309) of the evaluated protocols were effective, among which $85.45 \%(94 / 110)$ employed physical methods and $14.55 \%$ (16/110) utilized chemical methods. Of the 110 protocols, we selected those that exhibited rapid effects at low doses in sporulated and non-sporulated oocysts, described in Tables 2 and 3.

We observed statistically significant correlations between several characteristics of the protocols and their effectiveness from simple logistic regression analysis (Table 4). However, none of the multiple regression models were significant.

Comparisons of the two main groups of protocols (chemical and physical) for inactivating $T$. gondii oocysts revealed that physical methods were 2.35 times more likely than chemical methods to inactivate oocysts (Table 4).

Protocols that involved heat were most effective $(p<0.0001)$, having a 66.6 -fold greater likelihood of inactivating T. gondii oocysts than those that used refrigeration $(95 \% \mathrm{Cl}=8.61-515.02)$. The protocols that used ultraviolet 
Table 2. Treatments against sporulated oocysts of Toxoplasma gondii that were effective with short durations of exposure at low doses, 1973-2019.

\begin{tabular}{|c|c|c|c|c|}
\hline Author & Year & Chemical Treatment & Concentration & Time \\
\hline \multirow[t]{9}{*}{ Ito et al. (1975a) } & 1975 & Ammonium Sulfide PA & HDP & $1 \mathrm{~h}$ \\
\hline & & Methanol PA & HDP & $12 \mathrm{~h}$ \\
\hline & & Ethanol 99\% & $99 \%$ & $24 \mathrm{~h}$ \\
\hline & & Sulfa and Pyrimetramine & $1 \%$ & $3 \mathrm{~h}$ \\
\hline & & Ammonium hydroxide & $10 \%$ & $30 \mathrm{~min}$ \\
\hline & & Peracetic acid & $5 \%$ & $48 \mathrm{~h}$ \\
\hline & & N-Propyl alcohol & HDP & $48 \mathrm{~h}$ \\
\hline & & Neo Kurehasol (m-Cresol) & $1 \%$ & $48 \mathrm{~h}$ \\
\hline & & Formalin & $10 \%$ & $96 \mathrm{~h}$ \\
\hline Lindsay \& Dubey (2009) & 2009 & Salinity & $15 p p t \mathrm{NaCl}$ & 2 years \\
\hline \multicolumn{5}{|c|}{ Physical Thermal } \\
\hline Author & Year & Treatment & Temperature $\left({ }^{\circ} \mathrm{C}\right)$ & Time \\
\hline Kuticic \& Wikerhauser (1996) & 1996 & Freezing & -20 & 21 days \\
\hline Frenkel \& Dubey (1973) & 1973 & Freezing & -21 & 28 days \\
\hline \multirow[t]{4}{*}{ Dubey (1998) } & 1998 & Heating & 30 & 107 days \\
\hline & & & 35 & 16 days \\
\hline & & & 40 & 28 days \\
\hline & & & 45 & 3 days \\
\hline Ito et al. (1975b) & 1975 & Heating & 50 & $30 \mathrm{~min}$ \\
\hline Dubey (1998) & 1998 & Heating & 55 & $1 \mathrm{~min}$ \\
\hline $\begin{array}{c}\text { Kuticic \& Wikerhauser } \\
\text { (1996) }\end{array}$ & 1996 & Heating & 58 & 15 \\
\hline Dubey (1998) & 1998 & Heating & 60 & $1 \mathrm{~min}$ \\
\hline \multirow[t]{2}{*}{ Dubey (1998) } & & & 65 & $1 \mathrm{~min}$ \\
\hline & & & 70 & $1 \mathrm{~min}$ \\
\hline \multirow[t]{2}{*}{ Ito et al. (1975b) } & & Heating & 80 & $1 \mathrm{~min}$ \\
\hline & & & 90 & $30 \mathrm{seg}$ \\
\hline \multicolumn{5}{|c|}{ Physical Treatment } \\
\hline Author & Year & Irradiation & Concentration & Time \\
\hline $\begin{array}{l}\text { Dubey et al. (1996a); } \\
\text { Lacombe et al. (2017) }\end{array}$ & 1996 & Irradiation a & $0.20 \mathrm{kGy}$ & UR \\
\hline Ware et al. (2010) & 2010 & UV continued & $10 \mathrm{mj} / \mathrm{cm} 2$ & UR \\
\hline Dumètre et al. (2008) & 2008 & UV continued & $20 \mathrm{~mJ} / \mathrm{cm}^{-2}$ & $15 \min$ \\
\hline Author & Year & Pressure & Concentration & Time \\
\hline Lindsay et al. (2005) & 2005 & Pressure & $400 \mathrm{Mpa}$ & $1 \mathrm{~min}$ \\
\hline
\end{tabular}

HDP= High degree of purity; UR= unreported. 
Table 3. Treatments against non-sporulated oocysts of Toxoplasma gondii that were effective with short durations of exposure at low doses, 1973-2019.

\begin{tabular}{|c|c|c|c|c|}
\hline \multicolumn{5}{|c|}{ CHEMICAL TREATMENTS } \\
\hline Author & Year & Treatments & Concentration & Time \\
\hline \multirow[t]{3}{*}{ Ito et al. (1975a) } & 1975 & Sulfa and Pyrimetramine & $1 \%$ & $10 \mathrm{~min}$ \\
\hline & & Sulfa and Pyrimetramine & $5 \%$ & $5 \mathrm{~min}$ \\
\hline & & m-Cresol & $1 \%$ & $120 \mathrm{~min}$ \\
\hline \multicolumn{5}{|c|}{ THERMAL TREATMENTS } \\
\hline Author & Year & Treatments & Temperature $\left({ }^{\circ} \mathrm{C}\right)$ & Time \\
\hline \multirow[t]{3}{*}{ Frenkel \& Dubey (1973) } & 1973 & Freezing & -6 & 14 days \\
\hline & & Freezing & -21 & 1 day \\
\hline & & Thermal shock & -21 e $\mathrm{T}^{\circ}$ environment & 1 day \\
\hline \multirow[t]{6}{*}{ Ito et al. (1975a) } & 1975 & Heating & 37 & $48 \mathrm{~h}$ \\
\hline & & & 45 & $60 \mathrm{~min}$ \\
\hline & & & 50 & $2,5 \mathrm{~min}$ \\
\hline & & & 55 & $30 \mathrm{sec}$ \\
\hline & & & 60 & $10 \mathrm{sec}$ \\
\hline & & & 70 & $10 \mathrm{sec}$ \\
\hline
\end{tabular}

Table 4. Results of the simple logistic regression analysis showing the effects of different variables on the effectiveness of inactivation techniques for oocysts of Toxoplasma gondii, 1973-2019.

\begin{tabular}{|c|c|c|c|c|c|}
\hline Variable & $n / N$ & $\%$ & p-Wald & OR & (CI 95\%) \\
\hline \multicolumn{6}{|l|}{ Method Type } \\
\hline Chemicals & $16 / 73$ & 21.92 & & 1.00 & \\
\hline Physical & $94 / 236$ & 39.83 & 0.006 & 2.35 & $(1.29-4.44)$ \\
\hline \multicolumn{6}{|l|}{ Physicists Treatment } \\
\hline Room temperature* & $0 / 8$ & 0.00 & & & \\
\hline Cooling & $1 / 45$ & 2.17 & & 1.00 & \\
\hline Heating & $37 / 62$ & 59.68 & $<0.0001$ & 66.60 & $(8.61-515.02)$ \\
\hline Thermal shock & $4 / 16$ & 25.00 & 0.200 & 15.00 & $(1.53-143.93)$ \\
\hline Freezing & $7 / 18$ & 38.89 & 0.003 & 28.64 & $(3.18-257.54)$ \\
\hline Pressure & $4 / 8$ & 50.00 & 0.002 & 45.00 & $(4.01-505.11)$ \\
\hline Gamma irradiation & $5 / 17$ & 29.41 & 0.010 & 18.75 & $(2.00-176.02)$ \\
\hline Ultraviolet & $36 / 61$ & 59.02 & $<0.0001$ & 64.80 & $(8.37-501.45)$ \\
\hline \multicolumn{6}{|c|}{ Irradiation Treatment } \\
\hline \multicolumn{6}{|l|}{ Dose of oocysts } \\
\hline 1 to 100 & $15 / 18$ & 83.33 & & 1.00 & \\
\hline 101 to 1000 & $7 / 12$ & 58.33 & 0.14 & 0.28 & $(0.05-1.57)$ \\
\hline 1001 to 5000 & $1 / 9$ & 11.11 & 0.003 & 0.03 & $(0.00-0.28)$ \\
\hline
\end{tabular}

(n/N): n: sample number and N: population number. *Logistic regression was performed without this category. Cl: Confidence interval. OR: Odds ratio. 
Table 4. Continued...

\begin{tabular}{|c|c|c|c|c|c|}
\hline Variable & $n / N$ & $\%$ & p-Wald & OR & (CI 95\%) \\
\hline 5001 to 10000 & $9 / 14$ & 64.29 & 0.226 & 0.23 & $(0.07-1.88)$ \\
\hline More of 10000 & $9 / 25$ & 36.00 & 0.004 & 0.11 & $(0.03-0.50)$ \\
\hline \multicolumn{6}{|l|}{ Treatment } \\
\hline Gamma irradiation & $5 / 17$ & 29.41 & & 1.00 & \\
\hline Ultraviolet & $36 / 61$ & 59.02 & 0.036 & 3.46 & $(1.08-11.04)$ \\
\hline \multicolumn{6}{|l|}{ Heat treatment } \\
\hline \multicolumn{6}{|l|}{ Temperature } \\
\hline$-21^{\circ}$ to $0^{\circ} \mathrm{C}$ & $11 / 35$ & 31.43 & & 1.00 & \\
\hline 1 to $20^{\circ} \mathrm{C}^{*}$ & $0 / 41$ & 0.00 & & & \\
\hline $21^{\circ} \mathrm{C}$ to $40^{\circ} \mathrm{C}$ & $5 / 26$ & 19.23 & 0.288 & 0.52 & $(0.16-1.74)$ \\
\hline $41^{\circ} \mathrm{C}$ to $90^{\circ} \mathrm{C}$ & $33 / 48$ & 68.75 & 0.001 & 4.80 & $(1.88-12.28)$ \\
\hline \multicolumn{6}{|l|}{ Chemical Treatment } \\
\hline \multicolumn{6}{|l|}{ Oocyst } \\
\hline Sporulated & $12 / 67$ & 17.91 & & 1.00 & \\
\hline No Sporulated & $4 / 6$ & 66.67 & 0.016 & 9.20 & $(1.5-55.9)$ \\
\hline
\end{tabular}

$(\mathrm{n} / \mathrm{N})$ : $\mathrm{n}$ : sample number and N: population number. *Logistic regression was performed without this category. Cl: Confidence interval. OR: Odds ratio.

(UV) light $(p<0.0001 ; O R=64.8)$, pressure $(p=0.002 ; O R=45.00)$, freezing $(p=0.003 ; O R=28.64)$, and irradiation $(p=0.010 ; O R=18.75)$ were also effective as treatments (Table 4$)$.

Among the physical methods of irradiation, the protocols that used UV radiation were 3.46 times more likely to inactivate $T$. gondii oocysts ( $\mathrm{p}=0.036 ; 95 \% \mathrm{Cl}=1.08-11.04$ ) when compared to the techniques that used gamma irradiation. When the numbers of oocysts that were used in these studies was considered as a variable, we found that the protocols that treated numbers of oocysts ranging from 1 to 100 were more effective than those performed on numbers ranging from 1,001 to $5,000(p=0.003)$ and those on numbers of more than 10,000 oocysts $(p=0.004)$ (Table 4). When different genotypes of $T$. gondii were compared, the genotype III (46.00\%; 23/50) was more difficult to inactivate than genotype I $(64.29 \% ; 18 / 28)$, however there was no statistical significance.

Among the temperature-based treatments that were analyzed, those with temperatures between $41{ }^{\circ} \mathrm{C}$ and $90^{\circ} \mathrm{C}$ were 4.8 times more likely to inactivate $T$. gondii oocysts than those that used temperatures between $-21^{\circ} \mathrm{C}$ and $0^{\circ} \mathrm{C}$ (Table 4). When the maturity of oocysts was examined as a factor in the success of the treatment, we found that only $17.91 \%$ of the treatments on sporulated oocysts were effective. In contrast, treatment of non-sporulated oocysts was 9.20 times more likely to result in inactivation $(p=0.016 ; 95 \% \mathrm{Cl}=1.50-55.90)$ (Table 4$)$.

\section{Discussion}

Boiling of milk and cooking and salting of meat are effective techniques for inactivating tachyzoites and bradyzoites, respectively, what makes these foods potentially safer. The consumption of raw vegetables and drinking water containing T. gondii oocysts, in turn, tends to be the main cause of human toxoplasmosis outbreaks worldwide (Pinto-Ferreira et al., 2019) due to the high resistance of the biological form oocyst; no specific recommendations or methods currently exist to limit these routes of transmission. It is noteworthy that both sporulated and nonsporulated oocysts are significant for this study, since by preventing them from sporulating, they do not become infectious (Navarro et al., 1992; Dubey, 2004). After an ordered search, 16 articles that described 309 treatments against oocysts were selected, of which only $35.60 \%$ (110/309) were effective. These results were consistent with expectations, as studies indicate that oocysts are difficult to destroy using conventional methods (Dubey et al., 
1970a; Dubey, 2004). The parasite naturally encounters harmful environmental conditions, such as variations in humidity, salinity, temperature, solar radiation, and exposure to disinfectants (VanWormer et al., 2013); however, they remain infectious for months or years. This resistance is attributed to the ability of the cell walls of oocysts and sporocysts to largely retain their integrity, despite exposure to chemical and physical stressors (Freppel et al., 2018).

\section{Heat treatment}

The protocols that used heat were more effective. Oocysts exposed to $45^{\circ} \mathrm{C}$ for 60 minutes, $50^{\circ} \mathrm{C}$ for 2.5 minutes, $55^{\circ} \mathrm{C}$ for 30 seconds, or $60-70^{\circ} \mathrm{C}$ for 10 seconds did not become unviable. However, higher temperatures for longer durations were necessary to inactivate sporulated oocysts. For example, only $50^{\circ} \mathrm{C}$ for 30 minutes, $55-60{ }^{\circ} \mathrm{C}$ for 15 minutes, $70^{\circ} \mathrm{C}$ for 2 minutes, $80^{\circ} \mathrm{C}$ for 1 minute, and $90^{\circ} \mathrm{C}$ for 30 seconds were effective for this purpose. Hence, upon evaluating all previous studies utilizing heat treatments (Ito et al., 1975b; Kuticic \& Wikerhauser, 1996; Dubey, 1998), we may conclude that protocols that used temperatures between $41^{\circ} \mathrm{C}$ and $90^{\circ} \mathrm{C}$ were 4.8 times more likely to inactivate $T$. gondii oocysts when compared to techniques that used temperatures between $-21^{\circ} \mathrm{C}$ and $0{ }^{\circ} \mathrm{C}$. However, the use of high temperatures is not recommended for treating vegetables meant for raw consumption because they are perishable and extremely sensitive to heat.

Frenkel \& Dubey (1973) showed that the use of low temperature is an important technique for inactivating oocysts, although adequate time is essential for efficiency. Their study showed that non-sporulated oocysts are much more sensitive to inactivation techniques. When maintained at $-21^{\circ} \mathrm{C}$, non-sporulated oocysts were inactivated on day 1 , while sporulated oocysts were inactivated only on day 28 , and continued to elicit the production of antibodies. Further studies should be carried out to clarify the use of this technique and its real efficiency on oocysts before it is indicated as a food decontamination strategy.

\section{Chemical treatment}

Ito et al. (1975a) described various treatments with disinfectants, alcohols, and chemicals. In this study, sporulated oocysts were subjected to treatment with $99 \%$ ethanol for 48 hours, $99 \%$ methanol for 12 hours, $1 \%$ cresol for 48 hours, $10 \%$ and $28 \%$ liquid ammonia for 30 minutes, and $10 \%$ formalin solution for 96 hours. The protocols that used longer exposure times to the chemicals proved to be more effective. However, none of these treatments can be used for the decontamination of water and food, due to the large volume of chemicals required, the long durations of treatment, and the presence of residues.

\section{Physical methods}

As $T$. gondii oocysts are resistant to most chemical disinfectants, irradiation could be an effective method of destroying them in contaminated vegetables and fruits (Dubey et al., 1996a, 1998; Ware et al., 2010; Lacombe et al., 2017). Some previous studies with tachyzoites have shown that, in addition to killing the parasite, radiation can induce the production of antibodies in mice (Seah \& Hucal, 1975). The use of UV radiation was also effective in rendering oocysts unviable; moreover, this technique produces less byproducts when compared to chlorination and ozonation (von Gunten, 2003; Wainwright et al., 2007; Dumètre et al., 2008). When evaluating studies that used this technique (Dumètre et al., 2008; Ware et al., 2010), a non-linear sensitivity of oocysts to UV radiation was observed. This may be associated with the ability of the cell walls of oocysts and autofluorescent sporocysts to protect themselves from UV radiation (Lindquist et al., 2003) by using the energy absorbed from UV radiation for their autofluorescence. Although Dumètre et al. (2008) did find 4 log reduction of oocyst infectivity $40 \mathrm{~mJ}$ UV treatment, one mouse still got infected when inoculated with 50.000 oocysts, demonstrating a limitation of treatment.

Lacombe et al. (2017) demonstrated that gamma irradiation considerably reduces the viability of $T$. gondii in blueberries when a minimum dose of $0.2 \mathrm{kGy}$ was used. Other studies have also suggested that gamma radiation can be a successful intervention against the parasite (Dubey et al., 1998) because the high energy of the radiation breaks the chemical bonds in the molecules necessary for their growth and integrity, thus preventing their replication (Dubey et al., 1990). Moreover, low doses of gamma irradiation do not degrade the fruit or negatively affect its texture and color.

High pressure is commercially used to eliminate pathogens in a variety of food products (Flick, 2003). Lindsay et al. (2005) tested whether this method could be used to inactivate $T$. gondii in raspberries and found that $340 \mathrm{MPa}$ pressure for 60 seconds was sufficient to render the oocysts, present in raspberries, non-infectious for rats. 
This method should be further explored for treating raw vegetables due to its numerous advantages in terms of increasing their shelf life and maintaining their freshness, flavor, texture, and color (Tewari \& Juneja, 2007).

\section{Oocysts and strains of $T$. gondii}

Among the studies that we analyzed, protocols that treated contaminations of 1 to 100 oocysts were more efficient in inactivating oocysts than those that treated higher numbers of oocysts. Such a situation may be associated with the parasite's capacity for infectivity, because when using larger amounts of oocysts, the greater the probability that at least one or more oocysts will be able to infect. However, techniques for decontamination must be efficient regardless of the number of oocysts, as studies have shown that one $T$. gondii oocyst is sufficient to infect animals (Dubey, 1996; Dubey et al., 1996b).

The existence of three main strains of T. gondii, Type I, II, and III, which differ in their virulence and epidemiology (Sibley \& Boothroyd, 1992; AWWA, 1999; Lindsay et al., 2005), has been described in the literature. The VEG strain (Type III) was isolated from the blood of an individual with acquired immunodeficiency syndrome in 1989 and continues to be widely used in scientific studies, because it is a strain that produces large amounts of oocysts in experimental conditions (Dubey, 1998). When we compare the results of the selected articles relating inactivation and genotypes, the VEG strain was found to be more resistant to treatments than genotype I. Proteomics studies have demonstrated similarities in the molecules of the cell walls of genotypes II and III and suggested that the effect of genotype on its environmental resistance is negligible (Fritz et al., 2012; Possenti et al., 2013; Shapiro et al., 2019). However, Zhou et al. (2017) identified differences in protein expression between oocysts derived from an atypical strain and those derived from the Type II strain. Therefore, further studies are needed with different genotypes of oocysts, keeping all other variables constant to determine the association of the genotype with environmental resistance.

Excreted oocysts become infectious after sporulation, a process that results in the formation of two sporocysts, each with four sporozoites (Dubey et al., 1970b; Frenkel et al., 1970). In the present study, we observed that the environmental resistance of $T$. gondii oocysts is dependent on its maturity, such that the inactivation methodologies are more effective when used on the non-sporulated oocysts. Previous studies corroborate these findings and report that this greater resistance may be due to the additional presence of the sporocyst wall, which serves as a second level of protection (Dumètre et al., 2008; Fritz et al., 2012; Dumètre et al., 2013). Although oocysts have their own defense mechanisms against external stresses, it is known that the oocyst and sporocyst walls are the structures that provide chemical and mechanical protection to them (Dubey, 2004; Dumètre et al., 2013; Freppel et al., 2018). Finding a strategy to destroy this wall is the key to controlling $T$. gondii infections in humans and animals.

\section{Comparison between treatments}

Between the two main groups of treatments, physical treatments were more likely to inactivate oocysts, whereas oocysts were resistant to most chemical inactivation agents. These results may reflect the poor public health in places where supply systems use only chemical disinfectants such as chlorine. For example, many restaurants only use chlorinated aqueous solutions for decontamination of vegetables, without the concomitant use of filtered water (Jones \& Dubey, 2010). T. gondii has been isolated from samples of chlorinated drinking water, suggesting that this reagent has no action on the parasite, as it is not capable of permeating or disturbing the oocyst wall (Moura et al., 2006; Dumètre et al., 2013). Diluted solutions of household bleach can destroy the outer wall of the oocyst, but do not markedly alter the structure, mechanics, or permeability of the sporocyst wall or the inner wall of the oocyst. Therefore, exposure to bleach does not affect the infectivity of the sporozoite, but it can make oocysts more adherent than untreated cells (Dumètre et al., 2013). This adherent nature favors the aggregation of oocysts, concentrating them, and increasing the vulnerability of the host (Freppel et al., 2018). Ozone is another chemical that may be more efficient as a disinfectant than chlorine, as it oxidizes organic and inorganic compounds. However, in addition to the formation of undesirable byproducts such as bromate (von Gunten, 2003), ozone use may not be very effective because $T$. gondii oocysts have a high degree of resistance to it (Dumètre et al., 2008).

The tolerance of oocysts to environmental stressors, including salinity, may be attributed to the robustness, molecular contents, and lack of permeability of the oocyst walls (Shapiro et al., 2019). Lindsay \& Dubey (2009) demonstrated that oocysts can survive in seawater (15 ppt of $\mathrm{NaCl})$ at $4{ }^{\circ} \mathrm{C}$ for up to two year, and still undergo sporulation in that environment and remain infectious (Lindsay et al., 2003). Thus, techniques with the use of salt, prove to be inefficient for the inactivation of oocysts. 


\section{Conclusion}

The use of sanitizers in water, although effective against viruses and bacteria, has little or no action on T. gondii oocysts. Heat treatments have been shown to be fast-acting and effective. Their use in treating low volumes of water can be effective for inactivating the parasite. However, despite their effectiveness, heat treatments cause undesirable organoleptic changes in vegetables and therefore, they must be limited to vegetables that need to be cooked prior to consumption.

Among the other methodologies used, treatments with radiation and pressure were effective. Moreover, they do not substantially alter the physicochemical characteristics of food or adversely affect food quality. Thus, such treatments may be viable alternatives for controlling $T$. gondii and other parasites in vegetables. However, further studies are required before such treatments are used on these foods.

\section{References}

American Water Works Association Research Division Microbiological Contaminants Research Committee - AWWA. Committee Report: emerging pathogens -viruses, protozoa, and algal toxins. J Am Water Works Assoc 1999; 91(9): 110-121. http://dx.doi. org/10.1002/j.1551-8833.1999.tb08702.x.

Cole M, Kasuga F, Farber JM, Anderson W, Anelich L, Buchanan RL. Microorganisms in foods 8: use of data for assessing process control and product acceptance. New York: Springer; 2011.

Dabritz HA, Conrad PA. Cats and Toxoplasma: implications for public health. Zoo Publ Health 2010; 57(1): 34-52. http://dx.doi. org/10.1111/j.1863-2378.2009.01273.x. PMid:19744306.

Dubey JP. Infectivity and pathogenicity of Toxoplasma gondii oocysts for cats. J Parasitol 1996; 82(6): 957-961. http://dx.doi. org/10.2307/3284206. PMid:8973406.

Dubey JP. Bradyzoite-induced murine toxoplasmosis: stage conversion, pathogenesis, and tissue cyst formation in mice fed bradyzoites of different strains of Toxoplasma gondii. J Eukaryot Microbiol 1997; 44(6): 592-602. http://dx.doi. org/10.1111/j.1550-7408.1997.tb05965.x. PMid:9435131.

Dubey JP. Toxoplasma gondii oocyst survival under defined temperatures. J Parasitol 1998; 84(4): 862-865. http://dx.doi. org/10.2307/3284606. PMid:9714227.

DubeyJP. Toxoplasmosis: a waterborne zoonosis. Vet Parasito/ 2004; 126(1-2): 57-72. http://dx.doi.org/10.1016/j.vetpar.2004.09.005. PMid:15567579.

DubeyJP, FrenkelJK. Cyst-induced toxoplasmosis in cats.J Protozoo/1972; 19(1): 155-177. http://dx.doi.org/10.1111/j.1550-7408.1972. tb03431.x. PMid:5008846.

Dubey JP, Beattie CP. Toxoplasmosis of animals and man. Florida: CRC-Press; 1988.

Dubey JP, Miller NL, Frenkel JK. Characterization of the new fecal form of Toxoplasma gondii. J Parasitol 1970a; 56(3): $447-456$. http://dx.doi.org/10.2307/3277601. PMid:5467864.

Dubey JP, Miller NL, Frenkel JK, Frenkel AJK. The Toxoplasma gondii oocyst from cat feces.J Exp Med 1970b; 132(4): 636-662. http:// dx.doi.org/10.1084/jem.132.4.636. PMid:4927658.

Dubey JP, Kotula AW, Sharar A, Andrews CD, Lindsay DS. Effect of high temperature on infectivity of Toxoplasma gondii tissue cysts in pork. J Parasitol 1990; 76(2): 201-204. http://dx.doi.org/10.2307/3283016. PMid:2319420.

Dubey JP, Jenkins MC, Thayer DW, Kwok OC, Shen SK. Killing of Toxoplasma gondii oocysts by irradiation and protective immunity induced by vaccination with irradiated oocysts. J Parasitol 1996a; 82(5): 724-727. http://dx.doi.org/10.2307/3283882. PMid:8885879.

Dubey JP, Lunney JK, Shen SK, Kwok OCH, Ashford DA, Thulliez P. Infectivity of low numbers of Toxoplasma gondii oocysts to pigs. J Parasitol 1996b; 82(3): 438-443. http://dx.doi.org/10.2307/3284082. PMid:8636849.

Dubey JP, Thayer DW, Speer CA, Shen SK. Effect of gamma irradiation on unsporulated and sporulated Toxoplasma gondii oocysts. Int J Parasitol 1998; 28(3): 369-375. http://dx.doi.org/10.1016/S0020-7519(97)83432-7. PMid:9559356.

Dumètre A, Dubey JP, Ferguson DJP, Bongrand P, Azas N, Puech PH. Mechanics of the Toxoplasma gondii oocyst wall. Procl Natl Acad Sci 2013; 110(28): 11535-11540. http://dx.doi.org/10.1073/pnas.1308425110. PMid:23798399.

Dumètre A, Le Bras C, Baffet M, Meneceur P, Dubey JP, Derouin F, et al. Effects of ozone and ultraviolet radiation treatments on the infectivity of Toxoplasma gondii oocysts. Vet Parasitol 2008; 153(3-4): 209-213. http://dx.doi.org/10.1016/j.vetpar.2008.02.004. PMid:18355965. 
Ferreira FP, Caldart ET, Freire RL, Mitsuka-Breganó R, Freitas FM, Miura AC, et al. The effect of water source and soil supplementation on parasite contamination in organic vegetable gardens. Rev Bras Parasito/ Vet 2018; 27(3): 327-337. http://dx.doi.org/10.1590/ s1984-296120180050. PMid:30183998.

Flick GJ. High-pressure processing offers varied applications [online]. Global Aquacult Advocate; 2003 [cited 2020 Jan 10]. Available from: https://www.aquaculturealliance.org/advocate/high-pressure-processing-offers-varied-applications/

Frenkel JK, Dubey JP, Miller NL. Toxoplasma gondii in cats: fecal stages identified as coccidian oocysts. Science 1970; 167(3919): 893-896. http://dx.doi.org/10.1126/science.167.3919.893. PMid:4903651.

Frenkel JK, Dubey JP. Effects of freezing on viability of Toxoplasma oocysts. J Parasitol 1973; 59(3): 587-588. http://dx.doi. org/10.2307/3278803. PMid:4711675.

Freppel W, Ferguson DJP, Shapiro K, Dubey JP, Puech PH, Dumètre A. Structure, composition, and roles of the Toxoplasma gondii oocyst and sporocyst walls. Cell Surf 2018; 5(1): 100016. http://dx.doi.org/10.1016/j.tcsw.2018.100016. PMid:32743133.

Fritz HM, Bowyer PW, Bogyo M, Conrad PA, Boothroyd JC. Proteomic analysis of fractionated Toxoplasma oocysts reveals clues to their environmental resistance. PLoS One 2012; 7(1): e29955. http://dx.doi.org/10.1371/journal.pone.0029955. PMid:22279555.

Ito S, Tsunoda K, Shimada K, Taki T, Matsui T. Disinfectant effects of several chemicals against Toxoplasma oocysts. Nippon Juigaku Zasshi 1975a; 37(3): 229-234. http://dx.doi.org/10.1292/jvms1939.37.229. PMid:1238847.

Ito S, Tsunoda K, Taki T, Nishikawa H, Matsui T. Destructive effect of heating against Toxoplasma oocysts. Natl Inst Anim Health Q 1975b; 15(3): 128-130. PMid:1186913.

Jones J, Dubey J. Waterborne toxoplasmosis: recent developments. Exp Parasito/ 2010; 124(1): 10-25. http://dx.doi.org/10.1016/j. exppara.2009.03.013. PMid:19324041.

Kuticic V, Wikerhauser T. Studies of the effect of various treatments on the viability of Toxoplasma gondii tissue cysts and oocysts. In: Gross U, editor. Toxoplasma gondii. Berlin: Springer; 1996. (Current Topics in Microbiology and Immunology; vol. 219). http:// dx.doi.org/10.1007/978-3-642-51014-4_23.

Lacombe A, Breard A, Hwang CA, Hill D, Fan X, Huang L, et al. Inactivation of Toxoplasma gondii on blueberries using low dose irradiation without affecting quality. Food Control 2017; 73: 981-985. http://dx.doi.org/10.1016/j.foodcont.2016.10.011.

Lafferty KD. Can the common brain parasite, Toxoplasma gondii, influence human culture? Proc Bio/ Sci 2006; 273(1602): 27492755. http://dx.doi.org/10.1098/rspb.2006.3641. PMid:17015323.

Lebart L, Morineau A, Warwick KM. Multivariate descriptive statistical analysis: correspondence analysis and related techniques for large matrices. App/ Sto Models D Analysis 1984; 5(2): 175-178. http://dx.doi.org/10.1002/asm.3150050207.

Lindquist HDA, Bennett JW, Hester JD, Ware MW, Dubey JP, Everson WV. Autofluorescence of Toxoplasma gondii and related coccidian oocysts. J Parasitol 2003; 89(4): 865-867. http://dx.doi.org/10.1645/GE-3147RN. PMid:14533708.

Lindsay DS, Collins MV, Mitchell SM, Cole RA, Flick GJ, Wetch CN, et al. Sporulation and survival of Toxoplasma gondii oocysts in seawater.J Eukaryot Microbio/ 2003;50(1 Suppl): 687-688. http://dx.doi.org/10.1111/j.1550-7408.2003.tb00688.x. PMid:14736220.

Lindsay DS, Collins MV, Jordan CN, Flick GJ, Dubey JP. Effects of high pressure processing on infectivity of Toxoplasma gondii oocysts for mice. J Parasitol 2005; 91(3): 699-701. http://dx.doi.org/10.1645/GE-425R. PMid:16110575.

Lindsay DS, Dubey JP. Long-term survival of Toxoplasma gondii Sporulated oocysts in seawater.J Parasito/ 2009; 95(4): 1019-1020. http://dx.doi.org/10.1645/GE-1919.1. PMid:20050010.

Moura L, Bahia-Oliveira LMG, Wada MY, Jones JL, Tuboi SH, Carmo EH, et al. Waterborne toxoplasmosis, Brazil, from field to gene. Emerg Infect Dis 2006; 12(2): 326-329. http://dx.doi.org/10.3201/eid1202.041115. PMid:16494765.

Navarro IT, Vidotto O, Giraldi N, Mitsuka R. Resistência do Toxoplasma gondii ao cloreto de sódio e aos condimentos em linguiça de suínos. Bol Oficina Sanit Panam 1992; 112(2): 138-143. PMid:1531110.

Pinto-Ferreira F, Caldart ET, Pasquali AKS, Mitsuka-Breganó R, Freire RL, Navarro IT. Patterns of transmission and sources of infection in outbreaks of human toxoplasmosis. Emerg Infect Dis 2019; 25(12): 2177-2182. http://dx.doi.org/10.3201/ eid2512.181565. PMid:31742524.

Possenti A, Fratini F, Fantozzi L, Pozio E, DubeyJP, Ponzi M, et al. Global proteomic analysis of the oocyst/sporozoite of Toxoplasma gondii reveals commitment to a host-independent lifestyle. BMC Genomics 2013; 14(1): 183. http://dx.doi.org/10.1186/1471-216414-183. PMid:23496850.

R Foundation for Statistical Computing. R Core Team [online]. 2013 [cited 2020 Jan 10]. Available from: http//www. R-project.org Seah SKK, Hucal G. The use of irradiated vaccine in immunization against experimental murine toxoplasmosis. Can J Microbiol 1975; 21(9): 1379-1385. http://dx.doi.org/10.1139/m75-207. PMid:1182614. 
Shapiro K, Bahia-Oliveira L, Dixon B, Dumètre A, de Wit LA, VanWormer E, et al. Environmental transmission of Toxoplasma gondii: oocysts in water, soil and food. Food Waterborne Parasitol 2019; 15: e00049. http://dx.doi.org/10.1016/j.fawpar.2019. e00049. PMid:32095620.

Sibley LD, Boothroyd JC. Virulent strains of Toxoplasma gondii comprise a single clonal lineage. Nature 1992; 359(6390): 82-85. http://dx.doi.org/10.1038/359082a0. PMid:1355855.

Tenter AM, Heckeroth AR, Weiss LM. Toxoplasma gondii: from animals to humans. Int J Parasito/ 2000; 30(12-13): 1217-1258. http://dx.doi.org/10.1016/S0020-7519(00)00124-7. PMid:11113252.

Tewari G, Juneja VK. High-pressure processing of foods. In: Tewari G, Juneja VK, editors. Advances in thermal and non-thermal food preservation. New York: John Wiley \& Sons; 2007. p. 203-239. http://dx.doi.org/10.1002/9780470277898.ch12.

VanWormer E, Fritz H, Shapiro K, Mazet JAK, Conrad PA. Molecules to modeling: toxoplasma gondii oocysts at the human-animalenvironment interface. Comp Immunol Microbiol Infect Dis 2013; 36(3): 217-231. http://dx.doi.org/10.1016/j.cimid.2012.10.006. PMid:23218130.

von Gunten U. Ozonation of drinking water: part II. Disinfection and by-product formation in presence of bromide, iodide or chlorine. Water Res 2003; 37(7): 1469-1487. http://dx.doi.org/10.1016/S0043-1354(02)00458-X. PMid:12600375.

Wainwright KE, Lagunas-Solar M, Miller MA, Barr BC, Gardner IA, Pina C, et al. Physical inactivation of Toxoplasma gondii oocysts in water. Appl Environ Microbio/ 2007; 73(17): 5663-5666. http://dx.doi.org/10.1128/AEM.00504-07. PMid:17616618.

Ware MW, Augustine SAJ, Erisman DO, See MJ, Wymer L, Hayes SL, et al. Determining UV inactivation of Toxop/asma gondii oocysts by using cell culture and a Mouse Bioassay. Appl Environ Microbio/ 2010; 76(15): 5140-5147. http://dx.doi.org/10.1128/ AEM.00153-10. PMid:20543052.

Zhou DH, Wang ZX, Zhou CX, He S, Elsheikha HM, Zhu XQ. Comparative proteomic analysis of virulent and avirulent strains of Toxoplasma gondii reveals strain-specific patterns. Oncotarget 2017; 8(46): 80481-80491. http://dx.doi.org/10.18632/ oncotarget.19077. PMid:29113319. 